\title{
Benralizumabo veiksmingumas ir saugumas gydant sunkią nekontroliuojamą astmą
}

\author{
EFFICACY AND SAFETY OF BENRALIZUMAB FOR THE TREATMENT OF SEVERE \\ UNCONTROLLED ASTHMA
}

\author{
JOLITA PALAČIONYTE் \\ LSMU MA Pulmonologijos klinika
}

\begin{abstract}
Santrauka. Astma sergantiems pacientams dažnai nustatoma eozinofilija, kuri susijusi su ligos sunkumu, pablogèjusia plaučių funkcija ir padidèjusiu paūmèjimų dažniu. Benralizumabas - tai monokloninis antikūnas, kuris jungiasi prie eozinofilų paviršiuje esančių interleukino-5 (IL-5) receptorių ir sukelia tiesioginị, greitą ir beveik visišką eozinofilų išeikvojimą. Benralizumabas patvirtintas sunkia eozinofiline astma sergantiems pacientams, kuriems, skiriant gydymą didelèmis įkvepiamųjų gliukokortikoidų dozèmis ir ilgo veikimo $\beta_{2}$ agonistais, liga yra nekontroliuojama. Šioje apžvalgoje apibendrinami benralizumabo veiksmingumo ir saugumo duomenys iš SIROCCO, CALIMA, BORA, ZONDA ir ALIZE klinikinių tyrimų. Vertinant jų rezultatus, benralizumabas žymiai sumažino astmos paūmẻjimų dažnį ir geriamụjų gliukokortikoidų dozę, pagerino plaučių funkciją ir ligos simptomų kontrolę. Benralizumabas yra veiksmingas ir gerai toleruojamas vaistas. Dažniausiai pasireiškianti nepageidaujama reakcija, susijusi su benralizumabo vartojimu, yra virusinè viršutinių kvẻpavimo takų infekcija.

Reikšminiai žodžiai: sunki astma, paūmejjimas, benralizumabas, veiksmingumas, saugumas.

Summary. Patients with asthma often have eosinophilia which is associated with worsening asthma severity, decreased lung function and increased exacerbation frequency. Benralizumab is a monoclonal antibody that binds to the interleukin-5 (IL-5) receptors and induces direct, rapid, and nearly complete depletion of eosinophils. Benralizumab approved for patients with severe uncontrolled eosinophilic asthma despite high-dosage inhaled corticosteroids plus long-acting $\beta_{2}$-agonists. In this article data from clinical studies SIROCCO, CALIMA, BORA, ZONDA and ALIZE are reviewed. According to them, benralizumab significantly reduced asthma exacerbations and oral glucocorticoid-dose, improved lung function and disease symptom control. Benralizumab is effective and well-tolerated. Viral upper respiratory tract infection is the most frequent side effect, associated with the usage of benralizumab.
\end{abstract}

Key words: severe asthma, exacerbation, benralizumab, efficacy, safety.

\section{IVADAS}

Astma serga daugiau nei $315 \mathrm{mln}$. žmonių visame pasaulyje ir šis skaičius nuolat auga. Apie 5-10 proc. sudaro sunki nekontroliuojama astma, kurios gydymui skiriamos didelès įkvepiamųjų gliukokortikoidu dozès ir ilgo veikimo $\beta_{2}$ agonistai. Tačiau šio gydymo dažnai nepakanka, todèl vargina dieniniai ir naktiniai astmos simptomai, atsiranda kasdienès veiklos ir darbo apribojimai, kartojasi ligos paūmèjimai, padideja stacionarinio gydymo poreikis. Apie 50 proc. pacientų, sergančių sunkia ir nekontroliuojama astma, nustatomas eozinofilinis uždegimas, kuris susijęs su sutrikusia plaučių funkcija, išreikštais astmos simptomais, dažnesniais paūmèjimais ir komplikuota ligos eiga. Šiems pacientams gydyti papildomai skiriama biologine terapija, nukreipta prieš interleukiną-5 (IL-5). Benralizumabas yra trečios fazès klinikiniuose tyrimuose plačiai nagrinètas biologinis vaistas astmai gydyti (pagrindiniai klinikinių tyrimų duomenys pateikiami 1 lenteleje). Šis vaistas yra monokloninis antikūnas, kuris jungiasi prie eozinofilų paviršiuje esančių IL-5 receptorių, sukeldamas tiesioginị, greitą ir beveik visišką eozinofilų išeikvojimą. Benralizumabas skiriamas papildomam gydymui sergantiesiems sunkia nekontroliuojama eozinofiline astma. Pirmos trys vaisto dozès skiriamos kas keturias, vèliau kas aštuonias savaites, todėl sumažinamas vizitų pas gydytoją skaičius, lyginant su kitais biologinès terapijos vaistais.

\section{SIROCCO IR CALIMA KLINIKINIŲ TYRIMŲ DUOMENYS}

SIROCCO ir CALIMA - tai trečios fazès, atsitiktinių imčių, dvigubai akli, paralelinių grupių daugiacentriai tyrimai, kuriuose dalyvavo 2511 tiriamųjų (atitinkamai - 1205 ir 1306). SIROCCO tyrimas truko 48, CALIMA - 56 savaites. Šių tyrimų tikslas ivvertinti benralizumabo, kaip papildomo gydymo veiksmingumą ir saugumą pacientams, sergantiems sunkia nekontroliuojama astma su padidejusiu eo- 


\section{Farmakoterapija}

1 lentelè. Klinikiniai tyrimai, kuriuose tirtas benralizumabo veiksmingumas ir saugumas

\begin{tabular}{|l|c|c|c|c|l|}
\hline $\begin{array}{c}\text { Klinikinis } \\
\text { tyrimas }\end{array}$ & $\begin{array}{c}\text { Visi i tyrimą jitraukti } \\
\text { pacientai (n) }\end{array}$ & $\begin{array}{c}\text { Pacientuc } \\
\text { amžius (metai) }\end{array}$ & $\begin{array}{c}\text { Tyrimo } \\
\text { pabaiga (sav.) }\end{array}$ & $\begin{array}{c}\text { Vèlesnis } \\
\text { vizitas (sav.) }\end{array}$ & \multicolumn{1}{|c|}{ Pirminè vertinamoji baigtis } \\
\hline SIROCCO & 1205 & $12-75$ & 48 & 56 & Paūmejjimų dažnis \\
\hline CALIMA & 1306 & $12-75$ & 56 & 60 & Paūmejjimų dažnis \\
\hline BORA & 1926 & $12-75$ & $56(108)^{*}$ & 68 & Nepageidaujama reakcija \\
\hline ZONDA & 220 & $18-75$ & 28 & - & Geriamuju gliukokortikoidų dozė \\
\hline ALIZE & 103 & $12-21$ & 20 & - & Imuninis atsakas \\
\hline
\end{tabular}

*12-17 metų asmenims.

2 lentelè. Pagrindiniai SIROCCO ir CALIMA klinikinių tyrimų rezultatai, kai eozinofilų kiekis kraujyje $\geq 300$ ląstelių/ $\mu$ I

\begin{tabular}{|c|c|c|c|c|c|c|}
\hline & \multicolumn{3}{|c|}{ SIROCCO } & \multicolumn{3}{|c|}{ CALIMA } \\
\hline & \multirow{2}{*}{$\begin{array}{l}\text { Placebo } \\
\text { grupé }\end{array}$} & \multicolumn{2}{|c|}{ Benralizumabo grupès } & \multirow{2}{*}{$\begin{array}{l}\text { Placebo } \\
\text { grupé }\end{array}$} & \multicolumn{2}{|c|}{ Benralizumabo grupès } \\
\hline & & $\begin{array}{c}\text { Vaistą } \\
\text { skiriant kas } \\
4 \text { sav. }\end{array}$ & $\begin{array}{l}\text { Vaistą } \\
\text { skiriant kas } \\
8 \text { sav.* }\end{array}$ & & $\begin{array}{l}\text { Vaistą } \\
\text { skiriant kas } \\
4 \text { sav. }\end{array}$ & $\begin{array}{l}\text { Vaistą } \\
\text { skiriant kas } \\
8 \text { sav.* }\end{array}$ \\
\hline $\begin{array}{l}\text { Metinis astmos paūmèjimų dažnis } \\
\text { (95 proc. } \mathrm{PI} \text { ) }\end{array}$ & $\begin{array}{c}1,33 \\
(1,12-1,58)\end{array}$ & $\begin{array}{c}0,73 \\
(0,60-0,89)\end{array}$ & $\begin{array}{c}0,65 \\
(0,53-0,80)\end{array}$ & $\begin{array}{c}0,93 \\
(0,77-1,12)\end{array}$ & $\begin{array}{c}0,60 \\
(0,48-0,74)\end{array}$ & $\begin{array}{c}0,66 \\
(0,54-0,82)\end{array}$ \\
\hline $\begin{array}{l}\text { Paūmèjimų dažnio santykis lyginant } \\
\text { su placebu ( } 95 \text { proc. PI) }\end{array}$ & - & $\begin{array}{c}0,55 \\
(0,42-0,71)\end{array}$ & $\begin{array}{c}0,49 \\
(0,37-0,64)\end{array}$ & - & $\begin{array}{c}0,64 \\
(0,49-0,85)\end{array}$ & $\begin{array}{c}0,72 \\
(0,54-0,95)\end{array}$ \\
\hline $\begin{array}{l}\mathrm{FEV}_{1} \text { padidèjimas nuo pradinès } \\
\text { reikšmès (I) }\end{array}$ & 0,239 & 0,345 & 0,398 & 0,215 & 0,340 & 0,330 \\
\hline $\begin{array}{l}\mathrm{FEV}_{1} \text { padidejimo (I) skirtumas lygi- } \\
\text { nant su placebo ( } 95 \text { proc. } \mathrm{PI})\end{array}$ & - & $\begin{array}{c}0,106 \\
(0,016-0,196)\end{array}$ & $\begin{array}{c}0,159 \\
(0,068-0,249)\end{array}$ & - & $\begin{array}{c}0,125 \\
(0,037-0,213)\end{array}$ & $\begin{array}{c}0,116 \\
(0,028-0,204)\end{array}$ \\
\hline $\begin{array}{l}\text { Astmos simptomu kontrolès vertini- } \\
\text { mo balo sumažejimas nuo pradinès } \\
\text { reikšmės }\end{array}$ & $-1,04$ & $-1,12$ & $-1,30$ & $-1,16$ & $-1,28$ & $-1,40$ \\
\hline $\begin{array}{l}\text { Astmos simptomų kontrolès verti- } \\
\text { nimo balo sumažejimo skirtumas } \\
\text { lyginant su placebu ( } 95 \text { proc. PI) }\end{array}$ & - & $\begin{array}{c}-0,08^{* *} \\
(-0,27-0,12)\end{array}$ & $\begin{array}{c}-0,25 \\
(-0,45-0,06)\end{array}$ & - & $\begin{array}{c}-0,12^{* *} \\
(-0,32-0,07)\end{array}$ & $\begin{array}{c}-0,23 \\
(-0,43-0,04)\end{array}$ \\
\hline
\end{tabular}

$\mathrm{PI}$ - pasikliautinasis intervalas; * pirmas tris vaisto dozes skiriant kas keturias savaites; ${ }^{* *}$ statistiškai nereikšminga.

zinofilų kiekiu kraujyje. Abiems tyrimams atrinkti astma sergantys pacientai, kurie ne mažiau nei vienerius metus iki ịtraukimo ị tyrimą gydyti vidutinèmis arba didelėmis įkvepiamųjų gliukokortikoidų dozèmis ir ilgo veikimo $\beta_{2}$ agonistais. Kiti ịtraukimo kriterijai: ne mažiau nei 3 mèn. skirtas gydymas didelèmis įkvepiamųjų gliukokortikoidų dozèmis ir ilgo veikimo $\beta_{2}$ agonistais su (arba be) geriamųjų gliukokortikoidų ir papildomų astmą kontroliuojančių vaistų; dokumentuoti bent du astmos paūmèjimai per vienerius metus, kurių gydymui skirti geriamieji gliukokortikoidai arba didinta îprastinè jų dozė; padidèjęs iškvèpimo tūris per pirmą sekundę (angl. Forced Expiratory Volume in First Second, $\mathrm{FEV}_{1}$ ) $<80$ proc. (<90 proc. $12-17$ metų tiriamiesiems) prieš vartojant bronchų plečiamuosius vaistus atrankos metu; dokumentuota grịžtamoji kvėpavimo takų obstrukcija per 12 mèn. iki ịtraukimo ị tyrimą ir Astmos kontrolès klausimyno (angl. Asthma Control
Questionnaire-5; ACQ-5) bendras balas ne mažesnis nei 1,5 .

SIROCCO ir CALIMA klinikinių tyrimų dalyviai pagal skirtą gydymą atsitiktine tvarka suskirstyti $\underset{i}{\text { tris }}$ grupes santykiu 1:1:1. Vienoje jų pacientai gydyti poodiniu benralizumabu 30 mg kas keturias savaites, kitoje grupejje skirtas gydymas tuo pačiu vaistu ir tokia pačia doze, tačiau kas aštuonias savaites (pirmas tris dozes skiriant kas keturias savaites), trečioje - placebo injekcinis tirpalas kas keturias savaites. Tiriamieji taip pat suskirstyti ị dvi grupes pagal eozinofilų kiekị kraujyje santykiu 2:1: $\geq 300$ ląstelių/ $\mu \mathrm{l}$ ir $<300$ ląstelių/ $\mu$ l. Toks santykis pasirinktas siekiant didesnio pacientų skaičiaus su išreikšta eozinofilija, kadangi jiems tikètasi didesnès gydymo naudos, kartu vaisto efektyvumą palyginant su pacientais, kuriems nustatytas mažas pradinis eozinofilų kiekis kraujyje. Pirminè vertinamoji baigtis buvo paūmèjimų dažnis pacientams, vartojusiems dideles ¡Łkepiamųjų gliukokortikoidų dozes ir ilgo veikimo 
$\beta_{2}$ agonistus, kai pradinis eozinofilų kiekis kraujyje ne mažesnis nei 300 ląstelių/ $\mu$ l. Astmos paūmejjimas - tai būklès pablogèjimas, reikalaujantis: geriamųjų gliukokortikoidų vartojimo ne mažiau kaip tris dienas; anksčiau vartotos geriamųjų gliukokortikoidų dozès padidinimo; vienkartinès gliukokortikoidų injekcijos; skubios medicininès pagalbos (<24 val.) su geriamujuc arba injekcinių gliukokortikoidų poreikiu; stacionarinio gydymo. Pagrindinès antrinès vertinamosios baigtys: $\mathrm{FEV}_{1}$ prieš vartojant bronchų plečiamuosius vaistus ir astmos simptomų kontrolès vertinimas paskutinę tyrimo savaitę pacientams, kuriems eozinofilų kiekis kraujyje ne mažesnis kaip 300 ląstelių/ $\mu$ l. Papildomos antrinès vertinamosios baigtys: laikas iki pirmo astmos paūmèjimo, metinis paūmėjimų dažnis, dèl kurių reikejjo skubios pagalbos arba stacionarinio gydymo, $\mathrm{FEV}_{1}$ po bronchų plečiamųjų vaistų vartojimo.

Abiejų tyrimų rezultatai parodė, kad tiriamųjų grupėse, kuriose pradinis eozinofilų kiekis buvo $\geq 300$ ląstelių/ $\mu$ l, papildomam gydymui skiriant benralizumabą tiek kas keturias, tiek kas aštuonias savaites, statistiškai reikšmingai sumažèjo astmos paūmejjimų dažnis ir padidejo $\mathrm{FEV}_{1}$ prieš vartojant bronchų plečiamuosius vaistus, astmos kontrolès vertinimo balas statistiškai reikšmingai sumažejo benralizumabą skiriant kas aštuonias savaites (2 lentelè). Tiriamųjų grupių, kurių pradinis eozinofilų kiekis <300 ląstelių/ $\mu$ l, rezultatai pateikiami 3 lenteleje. Tiek SIROCCO, tiek CALIMA klinikinių tyrimų metu dažniausios nustatytos nepageidaujamos reakcijos: viršutinių kvépavimo takų infekcija, astmos paūmèjimas ir nazofaringitas.

\section{BORA KLINIKINIS TYRIMAS - SIROCCO IR CALIMA TYRIMŲ TĘSINYS}

BORA - tai dvigubai aklas, randomizuotas, paralelinių grupių tyrimas, kuris atliktas siekiant ịvertinti ilgalaikį benralizumabo saugumą ir toleravimą, gydant sunkia nekontroliuojama astma sergančius pacientus, dalyvavusius viename iš ankstesnių klinikinių tyrimų (SIROCCO arba CALIMA). Visi 1926 ị šį tyrimą įtraukti pacientai, kurie anksčiau gydyti 30 mg benralizumabo poodinėmis injekcijomis kas keturias arba aštuonias savaites, toliau tęsè tą patị gydymą tokia pačia gydymo schema. Tiriamieji, kuriems ankstesnių tyrimų metu kas keturias savaites skirtas placebo injekcinis tirpalas, atsitiktinai suskirstyti santykiu 1:1 ir naujai skirtas gydymas benralizumabu kas keturias arba aštuonias savaites (tris pirmas dozes skiriant kas keturias savaites). Šio tyrimo trukmè - 56 savaitès (12-17 metų asmenims tyrimas bus tęsiamas iki 108 savaičiu).

Pagrindine vertinamoji baigtis - vaisto saugumas ir toleravimas skiriant $\mathrm{ji}$ abiem gydymo schemomis suaugusiesiems per 56 savaičių gydymo laikotarpi, ịskaitant ir vẻlesnị 12 savaičių stebėsenos laikotarpị, o paaugliams - per 56 savaičiu gydymo laikotarpị. Svarbiausios antrinès vertinamosios baigtys: paūmèjimų dažnis ir $\mathrm{FEV}_{1}$ prieš vartojant bronchų plečiamuosius vaistus suaugusiesiems 56 savaičių gydymo laikotarpiu ir 12 savaičių stebėsenos laikotarpiu, o paaugliams per 56 savaičių gydymo laikotarpi.

Dažniausiai stebètos nepageidaujamos reakcijos visose grupėse: virusinės viršutinių kvèpavimo takų infekcijos (14-16 proc.), astmos paūmejjimas

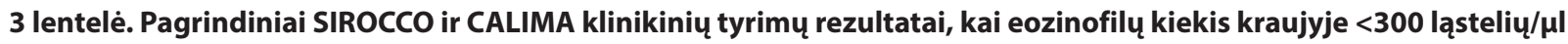

\begin{tabular}{|c|c|c|c|c|c|c|}
\hline & \multicolumn{3}{|c|}{ SIROCCO } & \multicolumn{3}{|c|}{ CALIMA } \\
\hline & \multirow{2}{*}{$\begin{array}{l}\text { Placebo } \\
\text { grupé }\end{array}$} & \multicolumn{2}{|c|}{ Benralizumabo grupès } & \multirow{2}{*}{$\begin{array}{l}\text { Placebo } \\
\text { grupé }\end{array}$} & \multicolumn{2}{|c|}{ Benralizumabo grupès } \\
\hline & & $\begin{array}{l}\text { Vaistą } \\
\text { skiriant kas } \\
4 \text { sav. }\end{array}$ & $\begin{array}{l}\text { Vaistą } \\
\text { skiriant kas } \\
8 \text { sav.* }\end{array}$ & & $\begin{array}{l}\text { Vaistą } \\
\text { skiriant kas } \\
4 \text { sav. }\end{array}$ & $\begin{array}{l}\text { Vaistą } \\
\text { skiriant kas } \\
8 \text { sav.* }\end{array}$ \\
\hline $\begin{array}{l}\text { Metinis astmos paūmèjimų dažnis } \\
\text { (95 proc. PI) }\end{array}$ & $\begin{array}{c}1,21 \\
(0,96-1,52)\end{array}$ & $\begin{array}{c}0,85 \\
(0,65-1,11)\end{array}$ & $\begin{array}{c}1,00 \\
(0,78-1,28)\end{array}$ & $\begin{array}{c}1,21 \\
(0,96-1,52)\end{array}$ & $\begin{array}{c}0,78 \\
(0,59-1,02)\end{array}$ & $\begin{array}{c}0,73 \\
(0,55-0,95)\end{array}$ \\
\hline $\begin{array}{l}\text { Paūmejjimų dažnio santykis } \\
\text { lyginant su placebu ( } 95 \text { proc. PI) }\end{array}$ & - & $\begin{array}{c}0,70 \\
(0,50-1,00)\end{array}$ & $\begin{array}{c}0,83^{* *} \\
(0,59-1,16)\end{array}$ & - & $\begin{array}{c}0,64 \\
(0,45-0,92)\end{array}$ & $\begin{array}{c}0,60 \\
(0,42-0,86)\end{array}$ \\
\hline $\begin{array}{l}\mathrm{FEV}_{1} \text { padidejjimas nuo pradinès } \\
\text { reikšmės (I) }\end{array}$ & 0,145 & 0,120 & 0,248 & 0,156 & 0,219 & 0,140 \\
\hline $\begin{array}{l}\mathrm{FEV}_{1} \text { padidejjimo (I) skirtumas } \\
\text { lyginant su placebu ( } 95 \text { proc. } \mathrm{PI})\end{array}$ & - & $\begin{array}{c}-0,025^{* *} \\
(-0,134-0,083)\end{array}$ & $\begin{array}{c}0,102^{* *} \\
(0,003-0,208)\end{array}$ & - & $\begin{array}{c}0,064^{* *} \\
(-0,049-0,176)\end{array}$ & $\begin{array}{c}-0,015^{* *} \\
(-0,127-0,096)\end{array}$ \\
\hline $\begin{array}{l}\text { Astmos simptomų kontrolès } \\
\text { vertinimo balo sumažèjimas nuo } \\
\text { pradinès reikšmès }\end{array}$ & $-0,77$ & $-0,97$ & $-1,06$ & $-0,95$ & $-1,11$ & $-0,95$ \\
\hline $\begin{array}{l}\text { Astmos simptomų kontrolès verti- } \\
\text { nimo balo sumažejjimo skirtumas } \\
\text { lyginant su placebu ( } 95 \text { proc. PI) }\end{array}$ & - & $\begin{array}{c}-0,20 * * \\
(-0,48-0,08)\end{array}$ & $\begin{array}{c}-0,29 \\
(-0,57-(-0,01))\end{array}$ & - & $\begin{array}{c}-0,16^{* *} \\
(-0,44-0,13)\end{array}$ & $\begin{array}{c}0,01^{* *} \\
(-0,28-0,29)\end{array}$ \\
\hline
\end{tabular}

PI - pasikliautinasis intervalas; * pirmas tris vaisto dozes skiriant kas keturias savaites; ${ }^{* *}$ statistiškai nereikšminga. 


\section{Farmakoterapija}

(7-10 proc.) ir tik iki 1 proc. sudarè pneumonija. Pacientams, kurie ankstesnių tyrimų metu gydyti benralizumabu, antraisiais gydymo metais astmos paūmejjimų dažnis ir $\mathrm{FEV}_{1}$, prieš vartojant bronchų plečiamuosius vaistus, kito nežymiai. Šio tyrimo metu nustatyta, kad, gydant benralizumabu antrus metus, vaistas išlieka tiek pat saugus ir gerai toleruojamas kaip ir pirmais gydymo metais, o naujų nepageidaujamų reakcijų nenustatyta.

\section{ZONDA KLINIKINIO TYRIMO DUOMENYS}

Tai trečios fazès, atsitiktinių imčių, dvigubai aklas, paralelinių grupių daugiacentris tyrimas, kuriame dalyvavo 220 sunkia kontroliuojama astma sergančių pacientų, vartojančių geriamuosius gliukokortikoidus. I tyrimą įtraukti pacientai, kurie daugiau nei 12 mèn. vartojo ne mažesnes nei vidutines ịkvepiamųjų gliukokortikoidų dozes kartu su ilgo veikimo $\beta_{2}$ agonistais ir daugiau nei 6 mèn. geriamuosius gliukokortikoidus, bent dvi savaites nekeitus dozès (prednizoloną - nuo 7,5 iki $40 \mathrm{mg}$ per parą arba kitą gliukokortikoidą lygiaverte doze). Tiriamieji pagal skirtą gydymą atsitiktine tvarka suskirstyti $\mathfrak{i}$ tris grupes santykiu 1:1:1: benralizumabą skiriant kas keturias savaites, kas aštuonias savaites (pirmas 3 dozes skiriant kas keturias savaites) ir placebą kas keturias savaites. Tiriamieji taip pat suskirstyti ị dvi grupes pagal eozinofilų kiekį kraujyje:

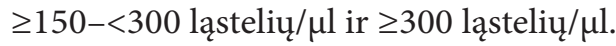

Pirminė vertinamoji baigtis - geriamųjų gliukokortikoidų dozès sumažèjimas. Antrinès vertinamosios baigtys: pacientų dalis, kuriems skiriant gydymą benralizumabu kas keturias arba aštuonias savaites, geriamųjų gliukokortikoidų dozė sumažèjo 25, 50 arba 100 proc., o vidutinė galutinè geriamųjų gliukokortikoidų dozè buvo ne didesnè nei $5 \mathrm{mg}$ (prednizolono arba kito gliukokortikoido lygiaverte doze), išlaikant astmos kontrolę ir astmos paūmejjimų dažnis per metus.

Benralizumabu gydytiems pacientams vaistą skiriant tiek kas keturias, tiek kas aštuonias savaites, gliukokortikoidų dozès mediana tyrimo metu sumažejo iki 75 proc., o placebo grupeje - iki 25 proc. $(\mathrm{p}<0,001)$ (pav.). 37 proc. pacientų, kuriems benralizumabas skirtas kas aštuonias savaites, 33 proc., gydymą skiriant kas keturias savaites ir 12 proc. placebo grupeje, vartojama gliukokortikoidų dozė sumažejo daugiau kaip 90 proc. nuo pradinès dozės, o 56 proc. tiriamųjų, kuriems gydymui skirtas benralizumas kas keturias savaites, 52 proc., gydymą skiriant kas aštuonias savaites ir 19 proc. placebo grupeje, gliukokortikoidu poreikis išnyko. Tyrimo metu pasiektos visos antrinės vertinamosios baigtys, susijusios su geriamųjų gliukokortikoidų dozės mažinimu. Vartojamų gliukokortikoidų dozè $\geq 50$ arba $\geq 75$ proc. dažniau sumažèjo benralizumabu kas keturias ir kas aštuonias savaites gydomiems pacientams lyginant su placebo grupe. Gliukokortikoidų dozès sumažinimo šansas buvo 4,09

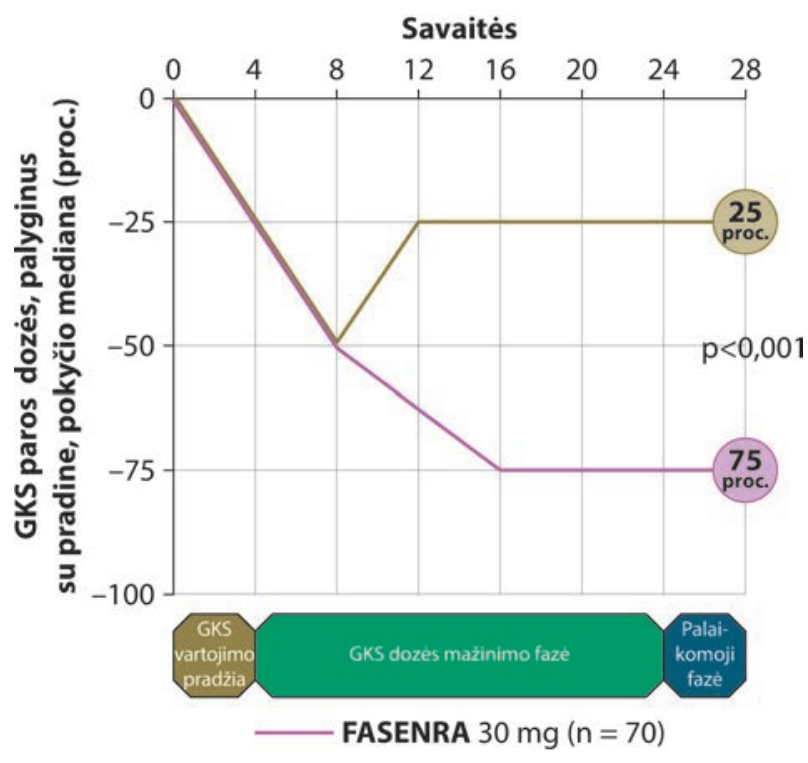

Pav. Gliukokortikoidų dozès sumažèjimas skiriant benralizumabą ir lyginat su placebo grupe

kartų didesnis (95 proc. PI 2,22-7,57) benralizumabą skiriant kas keturias savaites ir 4,12 kartų (95 proc. PI 2,22-7,63) - kas aštuonias savaites lyginant su placebo grupe. Metinis astmos paūmejjimų dažnis, benralizumabą skiriant kas aštuonias savaites, buvo 70 proc. mažesnis nei placebo grupejje.

\section{ALIZE KLINIKINIO TYRIMO DUOMENYS}

Tai trečios fazès, atsitiktinių imčių, dvigubai aklas, paralelinių grupių daugiacentris tyrimas, kuriame dalyvavo 103 nuo 12 iki 21 metų vidutinio sunkumo arba sunkia astma sergantys pacientai, gydomi vidutinėmis arba didelėmis įkvepiamųjų gliukokortikoidų dozèmis kartu su ilgo veikimo $\beta_{2}$ agonistais. Šio tyrimo tikslas - ivvertinti, ar kinta imuninis atsakas ị sezoninę gripo vakciną gydymui skyrus tris benralizumabo dozes. Tiriamieji pagal skirtą gydymą atsitiktine tvarka suskirstyti ị dvi grupes, santykiu 1:1. Pirmai grupei tris kartus kas keturias savaites skirta $30 \mathrm{mg}$ benralizumabo it paodi, antrai grupei - tris kartus kas keturias savaites placebo tirpalas. Abiem tiriamųjų grupėms aštuntą tyrimo savaitę skirta vakcina nuo gripo, o 20-tą tyrimo savaitę (12 savaičių po skiepijimo) vertintas imuniteto atsakas. Tyrimo rezultatai parodè, kad benralizumabo vartojimas neturi įtakos antikūnų susidarymui prieš gripo vakciną.

\section{APIBENDRINIMAS}

Benralizumabas yra trečios fazès klinikiniuose tyrimuose plačiai nagrinètas biologinis vaistas, patvirtintas papildomam sunkios eozinofilinès astmos gydymui, kai liga nekontroliuojama nepaisant vartojamų didelių ¡kvepiamųjų gliukokortikoidų dozių ir ilgo veikimo $\beta_{2}$ agonistų. Benralizumabas sukelia tiesioginị, greitą ir beveik visišką eozinofilų išeikvojimą, todèl greitai 


\section{Farmakoterapija}

pasireiškia klinikinis vaisto veiksmingumas. Atliktų klinikinių tyrimų duomenimis, skiriant gydymą benralizumabu kas aštuonias savaites (pirmas tris dozes skiriant kas keturias savaites), statistiškai reikšmingai sumažèja astmos paūmèjimų dažnis, vartojamų gliukokortikoidų dozès, pagerèja plaučių funkcija ir ligos simptomų kontrolè. Šis vaistas gerai toleruojamas, o dažniausiai nustatoma nepageidaujama reakcija - virusinė viršutinių kvėpavimo takų infekcija. Benralizumabo dozavimas patogus tiek medicinos personalui, tiek pacientui, nes vaistas tiekiamas užpildytuose švirkštuose, o vizitų pas gydytoją skaičius sumažinamas iki aštuonių kartų per pirmus gydymo metus, vèlesniais metais - iki 6-7 kartų.

LT-0458-03-19-RIA

\section{LITERATŪRA}

1. Bleecker ER, FitzGerald JM, Chanez P, Papi A, Weinstein SF, Barker P, et al. Efficacy and safety of benralizumab for patients with severe asthma uncontrolled with high-dosage inhaled corticosteroids and long-acting $\beta 2$-agonists (SIROCCO): a randomised, multicentre, placebo-controlled phase 3 trial. Lancet. 2016; 388(10056):2115-27.

2. FitzGerald JM, Bleecker ER, Nair P, Korn S, Ohta K, Lommatzsch $\mathbf{M}$, et al. Benralizumab, an anti-interleukin-5 receptor a monoclonal antibody, as add-on treatment for patients with severe, uncontrolled, eosinophilic asthma (CALIMA): a randomised, double-blind, placebo-controlled phase 3 trial. Lancet. 2016; 388(10056):2128-41.

3. Busse WW, Bleecker ER, FitzGerald JM, Ferguson GT, Barker P, Sproule S, et al. Long-term safety and efficacy of benralizumab in patients with severe, uncontrolled asthma: 1 -year results from the BORA phase 3 extension trial. Lancet Respir Med. 2019; 7(1):46-59.

4. O'Quinn S, Xu X, Hirsch I. Daily patient-reported health status assessment improvements with benralizumab for patients with severe, uncontrolled eosinophilic asthma. J Asthma Allergy. 2019; 12:21-33.

5. Nair P, Wenzel S, Rabe KF, Bourdin A, Lugogo NL, Kuna P, et al. Oral glucocorticoid-sparing effect of benralizumab in severe asthma. N Engl J Med. 2017; 376(25):2448-58.

6. Zeitlin PL, Leong M, Cole J, Mallory RM, Shih VH, Olsson RF. Benralizumab does not impair antibody response to seasonal influenza vaccination in adolescent and young adult patients with moderate to severe asthma: results from the Phase IIIb ALIZE trial. J Asthma Allergy. 2018; 11:181-92. 